\title{
The Social Context of Local Development in Jebucu, Romania
}

\author{
Tibor FARKAS ${ }^{1 *}$, Cristina-Bianca POCOL ${ }^{2)}$, Zsuzsanna KASSAI ${ }^{1)}$ \\ ${ }^{1)}$ Institute for Regional Economics and Rural Development, Szent István University, H-2103 Gödöllő, \\ Páter K. u.1. Hungary; \\ ${ }^{2)}$ Department of Economic Sciences, University of Agricultural Sciences and Veterinary Medicine, \\ 400372 Cluj-Napoca, Calea Manastur no. 3-5, Romania. \\ *)corresponding author, e-mail:farkas.tibor@gtk.szie.hu
}

BulletinUASVM Horticulture 72(1) / 2015

Print ISSN 1843-5254, Electronic ISSN 1843-5394

DOI:10.15835/buasvmcn-hort:10820

\begin{abstract}
The local development possibilities of a settlement are connected to the general social and economic status of the region, however local resources also can directly shape local develop capacity and outcomes. We examine the dynamics of regional and local possibilities in Jebucu, Romania using statistical data from Romania's National Statistical Office. Local data were also gathered with help of the research camp in Jebucu in the summer of 2013. Beside a questionnaire survey there were also interviews and documents used in the analysis. Due to its location in northwest Romania, the region has relatively favourable opportunities within the country. Although the population and the employment have declined recently, the average life expectancy has increased. Dynamic agglomeration processes have occurred around the larger cities of the region, and the impact of emigration from cities can be observed in the countryside as well. The development processes which have occurred in Jebucu can be regarde asd pivotal. On the one hand, there were local actors who took the lead in the community and initiated development efforts. The actors who initiated the progress possessed strong external networks of relations and strong initiative skills. On the other hand, external supporters and resources were also available. This study discusses the combination of internal and external resources which helped shape local development efforts.
\end{abstract}

Keywords: local community, local development, regional development

\section{INTRODUCTION}

There are several general processes in terms of the rural development in Central and Eastern Europe (decline of population, ageing, diversification in agriculture etc..) Among these circumstances some villages can achieve impressive development outcomes, while others move toward poverty and population loss. In recently completed work we investigate the emergence of differentiated patterns of development. The aim of this study is to highlight and analyze external and internal factors of the

\footnotetext{
1 The Hungarian name of the village - used by local people, too -is Zsobok.
}

community life and local society connected to the development prozess of Jebucu.

European rural areas are characterized by a great diversity, which makes it difficult to reach a consensus for defining the concept of rurality (Hoggart et al., 2014). The European Commission identifies various rural typologies depending on the physical-geographical, socio-economic, institutional and environmental conditions (European Commission, 2009). Diversity of rural areas can be found in other regions of the world as well. For example, the elements that differentiate rural areas in the United States of America are size, density and population occupations, revenues, poverty and proximity to metropolitan areas (Glasgow and Brown, 2012). 
According to Woods (2013), European rural areas represent independent and innovative entities, able to face the challenges brought by the globalization processes. At the same time, the rural space is a vulnerable environment. Among the elements that define its vulnerability can be mentioned are habitat, demography, agriculture and environment quality (Stângă and Grozavu, 2012). Horlings and Marsden (2012) talk about a "new paradigm of the rural": on the one hand, the influence of the urban renders it even more difficult to preserve the identity and sustainability of rural spaces. On the other hand, the new strategies based on bio-economics and eco-economics help to build new identities for these areas.

Romania is a country with a high proportion of rural areas, these areas representing over $87 \%$ of the total geography. From an administrative point of view, in 2013 there were 2861 communes and 12957 villages. According to the data provided by the National Institute of Statistics, Romania's rural population was 9.59 million people at the beginning of 2014 (https://statistici.insse.ro/ shop/, 2014), which represented $45.15 \%$ of the total population. Compared to the 1960 s, when the average of rural population was of $67.9 \%$, in 1990 the share reached 46.78\% (Pocol, 2013). In the following period, the proportion between rural and urban areas maintained around the value of $45 \%$. This propotion is very high compared with other countries from the EU, such as Denmark, Germany, United Kingdom (Merce and Pocol, 2008). Romania's rural areas face a process of demographic aging. This is caused by a low birth rate and by migration inside the borders of the country (e.g., to urban areas), as well as migration abroad. A positive aspect of migration abroad identified by Guran-Nica et al. (2010) is related to the financial resources of people working abroad, revenues in the form of remittances which can represent a great contribution to local and regional development (see also, Pocol and Teselios, 2009).

The most significant decline of the rural population in Romania is found in young age groups (aged $<30$ years). The diminishing of this demographic group as well as the exodus of young population has led to a marked decrease of the active population in rural areas. The employment rate for the rural population decreased from
$67.2 \%$ in 1996 to 51.9\% in 2012 (Pocol, 2013). Regarding professional status, the highest share of the employed population is represented by independent workers, employers and non-paid family workers. Agriculture, forestry and fishing remain the main occupations for people living in Romanian rural areas.

Some historical processes led to weakening of the local communities. Long decades of socialism depreciated the role of the individuals and communities. The forced collectivisation of agriculture and urbanization forced rural people to leave their home (Farkas, 2010). The trend of urbanization and the economic and ideological objectives of the previous political system resulted in gradual depopulation of the villages (especially the young and skilled migration layer), pauperization and aging of the population. The consequence of these trends and processes is an increased difficulty in maintaining and reproducing community life, initiating co-operation and organizing social economy.

In the summer of 2013 a research group with help of university students of Szent István University of Gödöllő conducted research in Jebucu, in county Sălaj in North-West region of Romania. The geographical situation of Jebucu is moderate, the nearest town (Huedin) is $10 \mathrm{~km}$, while the centre of the county (Zalău) is $55 \mathrm{~km}$ away.

The special development started as Irma Molnár, the new pastor arrived in the village in 1991. She and her husband co-ordinated the first humanitarian aids from Western countries, then they started to renew the church, the local roads, and the school. Revitalizing the local school required pupils. For this reason they established the Bethesda Children's Home and School Centre. In order to supply food to the centre, and with the help of international and local assistance and voluntary aid, a mill, bakery, pig- and cow-farm were established, along with additional gardening efforts.

The role of the leader, who initiated this kind of development is inevitable. They activate the external and internal resources with great enthusiasm, not sparing their own time and energy. Thus these people are called "local heroes." In next section however, we discuss that this kind 
of development requires not only local heroes, but strong local communities as well.

The children's home, and the agricultural cooperation built around it serve social purposes. They maintain a very close and strong social cohesion. Although the literature approaches in several ways the subject of social economy, in general, the social economy (or non-profit sector/ third sector) is such a sector that occupies an intermediate place between the state and the market; it performs both economic and social missions; it serves public interest and it is not intended for profit distribution, but for the reinvesting of revenues into the activities of nonprofit organizations (Frey, 2007).

\section{MATERIALS AND METHODS}

For this analysis different methods were applied. First, using data from the National Institute of Statistics we analysed the rural situation in Romania, and specifically the regional aspects of the North-West Region. Moreover, the local society, economic and other characteristics of Jebucu were examined within the frame of a research in the summer of 2013. A face-to-face questionnaire survey was conducted in eighty households of Jebucu. Since it is a small hamlet, it was not necessary to select a sample. Rather, the whole population was surveyed as a census. In addition, semi-structured interviews were made with the key actors of local rural development. Information was also collected from different documents related to this research topic.
Among others the main characteristics and correlations of the local society were examined. We assumed that the community can achieve any sustainable development only if it possesses social capital. On the basis of the concepts of Pierre Bourdieu (1986), James S. Coleman (1988), Robert D. Putnam $(1993,1995)$, Francis Fukuyama $(1995,2002)$ (cited by Kassai - Farkas - Oláh, 2013) the social capital is a mixture of trust, relations, norms regulating social behaviour and civil social activity. Therefore, three dimensions of the social capital of local community were surveyed: first, the relations among the members of the local community, then the level of general and strategic trust and finally, the civil activity. In addition, the opinions of local inhabitants were also studied as a means of further assessing the type and degree of local social capital and community attachment.

Moreover, we used survey data to assess satisfaction with income, housing, environment, sanitary conditions, school quality, occupations and employment, public security, entertainment facilities, community life of the settlement, and general satisfacgtion of the local population. The respondents could mark the level of general and strategic trust, civil activity, satisfaction and happiness on an ordinal scale in the questionnaire.

For the analysis first frequency distributions were calculated. Based on the literature there are significant relations among the demographic, social factors and the level of trust. Therefore, the relations among the gender, age, family status,

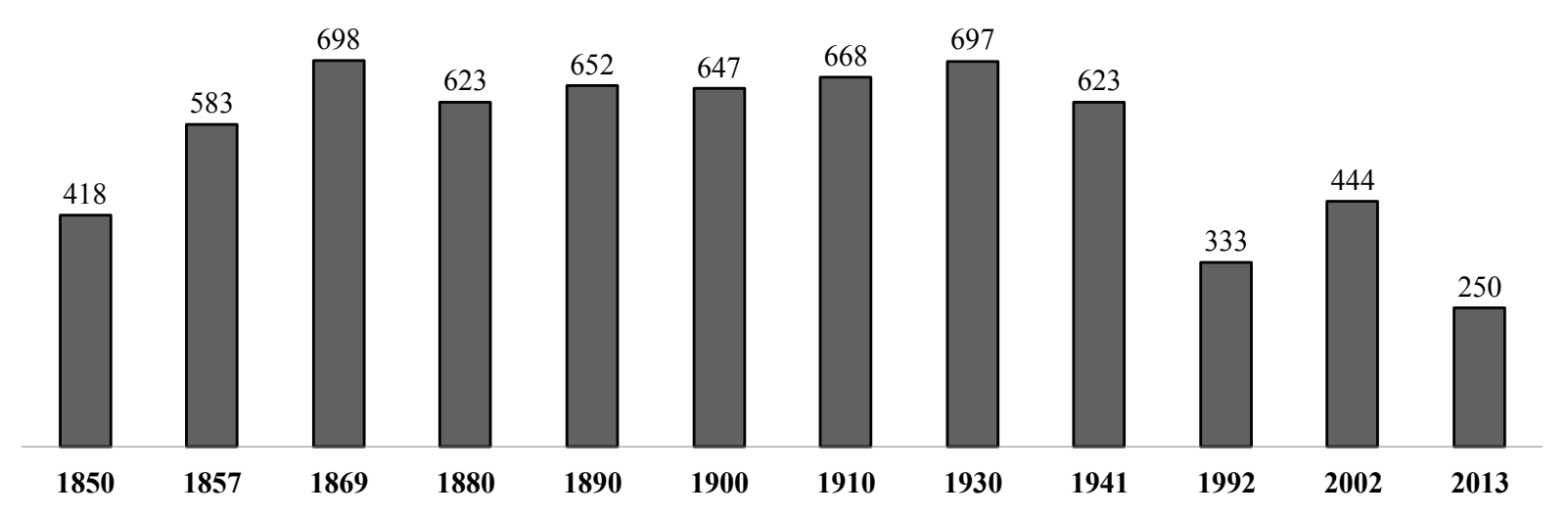

Fig. 1. Population of Jebucu between 1850 and 2013 (number of inhabitants) Source: Own edition based on http://varga.adatbank.transindex.ro 
school qualification and economic activity of respondents and the level of general and strategic trust were studied as well. Cross-tabulations were used for the examination of relations among the above mentioned non-metric variables. The significance level was set to $0.05(5 \%)$.

The relationships between happiness feeling and different elements of satisfaction were also examined by cross-tabulation analysis. To compute the measures of associations between these ordinal variables, a Somers'd statistic was used.

\section{RESULTS AND DISCUSSION}

The following graph (Figure 1) shows population size of Jebucu between 1850 and 2013 . Depopulation trends between 1941 and 1992 are clearly illustrated, as well as increases after 1992. Unfortunately the number of births is at very low level in the village, thus the demographic challenges clearly remain.

Unlike population dynamics, the social life and the social activities are well developed in Jebucu. In order to achieve higher quality of live there is a need for strong social capital in the community. A wide range of literature (e.g. Füzér et al., 2005) suggests how social capital has an essential role in sustainable rural development, too. Where social capital is weak, there are conflicting values and a lack of trust, which hinder any economic or social development activities. If there is a low level trust between the local actors the transactional and administrative costs of business activities are going to increase, which results in the loss of efficiency (Tóth and Jóna, 2012). Moreover, it often results in personal distress and higher mortality rates. Social capital can make a significant contribution to poverty alleviation. Therefore, there was examined how large the social capital of the society of Jebucu is.

Jebucu is a small village with approximately 250 inhabitants. For this reason, the overwhelming majority ( $81 \%$ of the population) stated that they knew everybody and a further $10 \%$ stated that they knew "almost everyone" in the village. Therefore, personal communication is very frequent among community members. The survey confirmed that the inhabitants saw their immediate neighbours most often, and in most cases on a daily basis. For this reason, mutual assistance is also the most frequent among immediate neighbors (see Figure 2). Many elderly people are in need of help, and in many cases their (younger) neighbours assist with shopping, cooking or helping around the house (e.g. shoveling snow, chopping wood, and so forth). We found that circles of friends also see each other regularly; more than three-quarters of them meet at least once a week. The majority of respondents stated that they less often met with their relatives, because they often lived in another place.

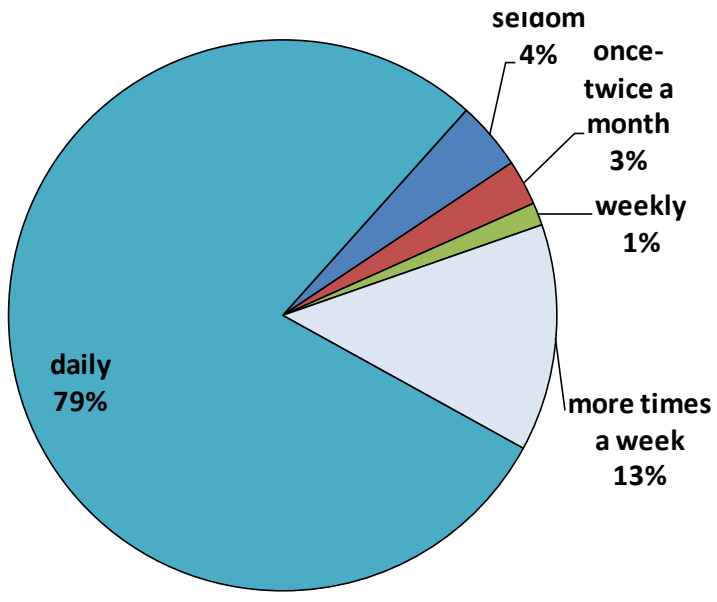

Fig. 2. Frequency of communication with neigbours in Jebucu (\%)

Source: Own edition based on own questionnaire survey, 2013

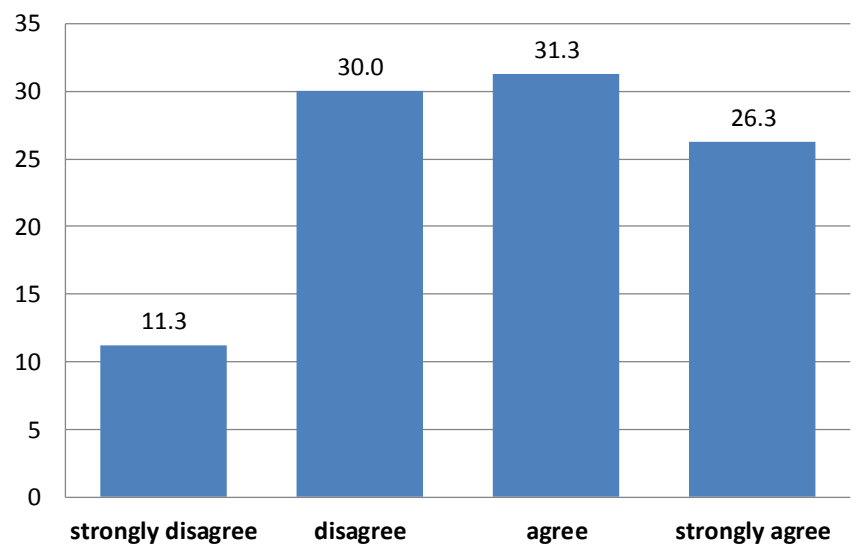

Fig. 3. General trust in Jebucu (\%)

Source: Author's own data from questionnaire survey, 2013 
The second examined factor of social capital was trust. The general and the strategic trust of the population of Jebucu were surveyed. Since the villagers have known each other well and they have been often in need of help, they did not feel they were exploited, so the level of general trust was high in Jebucu. The research findings proved that general trust felt towards foreign people was much stronger in Jebucu than in other Romanian and Hungarian settlements which participated in World Value Survey in 2005. Majority (57\%) of respondents considered that they could place their trust in most people in general (see Figure 3 ). In the international survey this value was only $20 \%$ in case of other Romanian settlements on the average.

A cross-tabulation analysis revealed that there is a significant relation among the economic activity of respondents and the level of general trust. It was found that mainly the pensioner and unemployed respondents did not trust in people from outside Jebucu. Some of them had less empathic personalities, while others had gained unpleasant experiences regarding general trust in the past. It turned out that other demographic and social factors for which we had data did not significantly influence the level of general trust.

Of course the strategic trust, which is based on experiences with friends and familiy members was even stronger than the general trust in the village (Fig. 4.). Only a few people did not trust in their relatives. According to the findings of cross-tabulation analyses among the examined demographic factors only the family state of respondents influenced the level of strategic trust significantly. Mainly those people did not possess strong levels of this kind of trust had gotten divorced or were otherwise disappointed in their spouse or relatives due to earlier negative experiences.

We found that trust towards friends was very high in Jebucu (see Figure 4). The survey data showed that three-quarters of the inhabitants highly trusted their friends. Based on this fact it can be stated that the villagers are not isolated, even they are opened and friendly.

The last studied component of social capital was civil social activity, which can be also considered very high within the settlement. Almost two-thirds of the population was regularly engaged in some kind of voluntary service. Residents often supported community programmes. For instance, some have cooked or baked, others packed or cleaned public spaces, and so forth, and more of them have participated in the maintenance and decoration of church or the preservation of cemetery. Many women have worked voluntarily in the elementary school and the children's home. Some of the villagers have made tablecloth, sold them and spent the income for community purposes. Men have mainly participated in renewing and building community buildings or agricultural works voluntarily.

\section{family members}

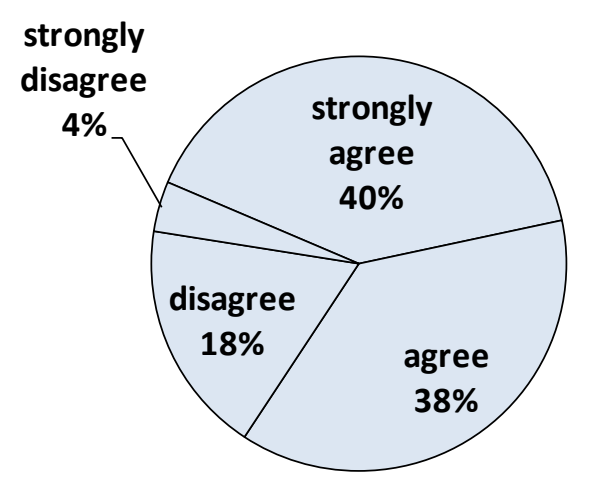

friends

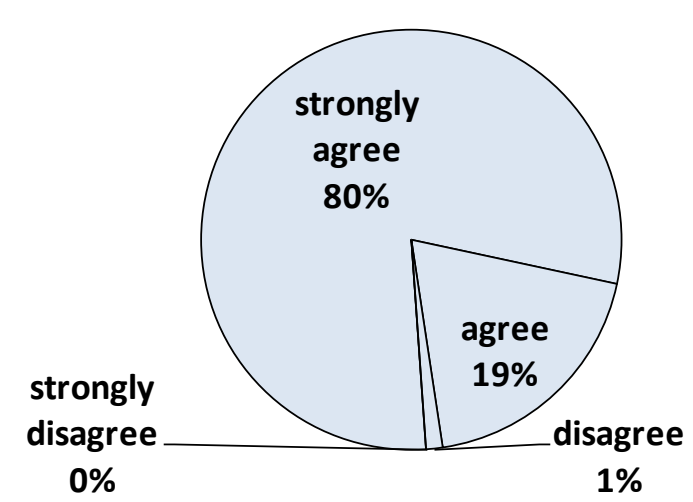

Fig. 4. Strategic trust in Jebucu (\%)

Source: Author's own data from questionnaire survey, 2013 
In addition, almost one third of the villagers were members at least in one civil organization. It turned out however much more people have taken part actively in the activities of civil organizations; they just have not been official members of these organizations. The Democratic Alliance of Hungarians in Romania, the Cultural Association for Jebucu and Calvinist Woman's Association are the strongest civil organizations in numbers. The significant overlaps of membership of civil organizations however has caused serious problems from time to time, because there have not been enough people to implement each action.

The state of mind of local inhabitants significantly influences the degree of social capital in the local society. The results of examination of anomie pointed out that the situation was much more favourable in Jebucu than in settlements that took part in Hungarostudy survey. The research highlighted that the inhabitants of Jebucu could find their way around the things of life more easily, the extent of social solidarity and collective support was larger, more people saw the point of planning, thus less people lived from one day to the next. These findings have also confirmed that the social capital of the society was very large in Jebucu.

It turned out that local people were very satisfied with their living circumstances in Jebucu; more than $90 \%$ of the population of Jebucu were satisfied with their life in general. We found that the inhabitants were the least satisfied with their income, sanitary conditions and school qualifications. On the other hand, the respondents were the most satisfied with their house, the environment, and the community life. It was observed that the majority was quite satisfied with the public security (91\%) and their job (80\%) as well. It also came to light that the majority (85\%) felt they were happy in Jebucu.

The the relations between the different components of satisfaction and happiness were also examined by cross-tabulation analyses. It was concluded that - contrary to all expectation - there were no significant relations among happiness and satisfaction with sanitary conditions, public security and community life. On the other hand, satisfaction with income, occupation, school qualification, house and environment significantly influenced the level of happiness of the respondents. The strength of relations between these ordinal variables were examined by Somers'd statistic (Table 1).

The above table shows that satisfaction with occupation has the largest influence on general happiness and satisfaction. While satisfaction with income is in second place, environment is in third place. Satisfaction with school qualification and house play however smaller role in the formation of happiness feeling.

\section{CONCLUSION}

Jebucu and similar peripheral and disadvantaged communities have to face many problems. According to G. Fekete (2012), the less rated resources (nature, culture and community) of the periphery in the modernization could be appreciated in postmodernism. In most cases the local community is characterized by counter selection, lack of education, and low levels of consumption. Businesses try to avoid these areas inter alia due to the lack of infrastructure. Local actors usually have weak external relations and less initiative. This study proves that in case of Jebucu these general rural tendencies differ.

While organizing and coordinating the development of local communities there is a prominent role of so called key people in critical leadership roles (Makkos et al., 2012). Some call them local heroes, others fate changers. The concept of local hero is meant the leaders who - unsparing their energy, sometimes family life - undertake the development of the local community. The question is raised as whether all local communities are able to produce their own local hero.

The special geographical, ethnic, religious isolation of Jebucu helped to protect the internal values of the village, to stick together and strengthen the local community and to keep out of the mainly negative social impacts on rural areas. The investigations have confirmed that the employment is in very favourable position in Jebucu. This situation is fully linked with the creation of children's home and the related social system.

In the life of Jebucu the children's home represents the recent past, the present and the near future. The home is a key factor for Jebucu's existence, because without it, due to the low 
number of local children, there would be no primary school. Without primary school young families probably would leave Jebucu. Without children's home there would be not enough jobs in the village, since about 60 people are employed here.

Overall, the changes over the past twenty years are positive. For a time, they managed to delay the decline the population of the village, young married couple remained in the village, preserved the school, created new jobs and homes in the village and become more and more capable of self-support. The future is however not absolutely optimistic and without challenge. The demographic situation is still not resolved, and the population is still in decline. For further development there is a need for a stable micro regional labour market and improved extension and vocational system.

There is a proposal to start a community development process in Jebucu, which will result in the developed cooperation of various actors, the church, the local leaders, aid agencies, donors, local NGOs, stakeholders and the local community. The development prozess usually starts with local community development, which will enhance the trust, mutual understanding and interctions inside of the community.

\section{REFERENCES}

1. Bourdieu P (1986). The forms of capital. In: Angelus, R. (eds.) (1997): A társadalmi rétegződés komponensei. Új Mandátum, Budapest, Hungary, pp. 156-177.

2. Coleman JS (1988). Social Capital in the Creation of Human Capital. In: The American Journal of Sociology, 94 (Supplement), pp. 95-120.

3. Farkas T, Dávid L (2010). Székelyvécke avagy egy falukutató tábor tapasztalatai/Székelyvécke or Experiences of a Village Research Camp. Gödöllő, Szent István Egyetem.

4. Frey M (2007). Szociális gazdaság kézikönyv/Handbook of Social Economy. Budapest, OFK.

5. Fukuyama F (1995). Social Capital and the Global Economy: A Redrawn Map of the World. In: Foreign Affairs, 74 (5), pp. 89-103.

6. Fukuyama F (2002). Social Capital and Development: The Coming Agenda. In: SAIS Review, 22 (1), pp. 23-37.

7. Füzér K, Gerő M, Sik E, Zongor G (2005). A társadalmi tőke növelésének lehetőségei fejlesztéspolitikai eszközökkel. Fejlesztéspolitika társadalmi hatásai 4. TÁRKI, Budapest, Hungary. At: http://www.tarki.hu/adatbank-h/kutjel/ pdf/a768.pdf, last accessed July 2011.
8. Fekete GÉ (2012). Perifériák válaszúton (konferenciaelőadás)/Peripheries on Crossroad (conference-lecture). Gödöllő.

9. Glasgow N, Brown DL (2012). Rural ageing in the United States: Trends and contexts. In: Journal of Rural Studies, 28(4), pp. 422-431.

10. Guran-Nica L, Marin C, Todica-Stefan N (2010). Migration Movements in the Romanian Rural Space (1990-2008). In Proceedings of the 5th WSEAS International Conference on Economy and Management Transformation, (2), pp. 503-507.

11. Hoggart K, Black R, Buller H (2014). Rural Europe. Identity and Change. Routledge, New York, USA.

12. Horlings LG, Marsden TK (2014). Exploring the 'New Rural Paradigm 'in Europe: Eco-economic strategies as a counterforce to the global competitiveness agenda. In: European Urban and Regional Studies, 21 (1) pp. 4-20.

13. Zsuzsanna Kassai, Tibor Farkas, Izabella Oláh (2013): Building Social Capital through Local Rural Development Partnerships in Hungary In: Takáč Ivan (ed.) Social \& Economic Transformations Affecting Rural People and Communities in Central \& Eastern Europe Since 1990. Nitra: Slovak Agricultural University, 2013. pp. 1-2.

14. Makkos D, Schwertner J, Ónodi ZS. (2012). Kincs ami nincs - Esettanulmány mint módszer a helyi gazdaság-fejlesztési kezdeményezések értékelésében és tervezésében/Non-existing treasure - Case Study as Method for the Evaluation and Planning of Local Economic Development Initiatives. In: Falu Város Régió. 2012. 1-2. pp. 25-31.

15. Merce E, Pocol CB (2009). Economie rurală. Editura AcademicPres, Cluj Napoca, Romania.

16. Pocol CB (2013). Economie Rurală. Identitate și actualitate. Editura AcademicPres, Cluj Napoca, Romania.

17. Pocol CB, Teselios CM (2009). The effects of labour force migration to Italy and Spain in 2004-2008 on Romania's Regional Development. Scientific Papers, 121.p.

18. Putnam RD (1993). The Prosperous Community: Social Capital and Public Life. In: The American Prospect, 13 (4), pp. 35-42.

19. At: http://prospect.org/cs/articles?article=the_prosperous_community, last accessed in July 2013.

20. Putnam RD (1995). Bowling Alone: America's Declining Social Capital. In: Journal of Democracy, 6 (1), pp. 65-78.

21. At: http://xroads.virginia.edu/ HYPER/DETOC/assoc/ bowling.html, last accessed in July 2013.

22. Stângă IC, Grozavu A (2012). Quantifying human vulnerability in rural areas: case study of Tutova Hills (Eastern Romania). In: Natural Hazards and Earth System Science, 12(6), pp. 1987-2001.

23. Tóth T, Jóna GY (2012). Concepts of the Territorial Capital. In: SELYE E-STUDIES, pp. 1-15. At: http://selyeuni.sk/ gtk/e-studies/en.html, last accessed in August 2013.

24. Woods M (2013). Rural development, globalization and European regional policy: perspectives from DERREG project. In: Geographia Polonica, 86 (2), pp. 99-109. 
25. ${ }^{* * *}$ European Commission, European Network for Rural Development, 2009, Rural typologies and territorial particularities. At: http://enrd.ec.europa.eu/policyin-action/improving-implementation/typologies-andtargeting/ro/typologies-and-targeting_ro.cfm,last accessed in January, 2013.
26. ***National Institute of Statistics, TEMPO-Online Data basis. At: https://statistici.insse.ro/shop/, last accessed in August, 2014.

27. ${ }^{* *}$ North West Agency for Regional Development, Development plan for the region NV 2014-2020. At: http://www.nord-vest.ro, last accessed in August, 2014. 